\title{
Penggunaan Tentara Anak Oleh Aktor Selain Negara Ditinjau Dari Hukum Humaniter Internasional
}

\author{
Rahadian Diffaul Barraq Suwartono \\ Fakultas Hukum Universitas Islam Indonesia Yogyakarta Indonesia \\ Jln. Tamansiswa 158, Yogyakarta Indonesia \\ diffaul@gmail.com
}

Received: 22 Januari 2020; Accepted: 20 Oktober 2020; Published: 15 Desember 2020

https://doi.org/10.20885/iustum.vol27.iss3.art5

\begin{abstract}
The use of children as combatants is not only carried out by the state, but also by actors other than the state. Children aged 8 to 14 are armed, trained and fielded in combats. The recruitment of child soldiers is generally prohibited by international law. There are several international legal instruments that prohibit the involvement of child soldiers in armed conflict. However, so far international legal arrangements have emphasized obligations on state subjects. This results in unclear regulations and legal accountability for the use of child soldiers by non-state actors. This research answers two problem formulations, First, how is the practice of using child soldiers by non-state actors?; Second, what is the concept of the responsibility of non-state actors for the crime of using child soldiers in international humanitarian law? This research is a normative study, using a statutory, historical, and conceptual approach. The results of this study concluded: First, the practice of using child soldiers in the field by non-state actors was carried out by recruiting their child soldiers forcibly and voluntarily, treating them very inhumanely, and assigning various kinds of child soldiers on their side based on age and sex; Second, the responsibility for a person who commits crimes using child soldiers can be in the form of individual responsibility or command responsibility.
\end{abstract}

Key Words: Armed conflicts; child soldiers; non-state actors

\section{Abstrak}

Penggunaan anak-anak sebagai kombatan bukan hanya dilakukan oleh negara, namun juga oleh aktor selain negara. Anak-anak usia 8 hingga14 tahun dipersenjatai, dilatih, dan diterjunkan dalam pertempuran. Perekrutan tentara anak secara umum dilarang oleh hukum internasional. Terdapat beberapa instrumen hukum internasional yang melarang keterlibatan tentara anak dalam konflik bersenjata. Namun, selama ini pengaturan-pengaturan hukum internasional lebih menekankan kewajiban pada subyek negara. Hal ini mengakibatkan ketidakjelasan pengaturan dan pertanggungjawaban hukum atas penggunaan tentara anak oleh aktor selain negara. Penelitian ini menjawab dua rumusan masalah, Pertama, bagaimanakah praktik penggunaan tentara anak oleh aktor selain negara?; Kedua, bagaimana konsep pertanggungjawaban aktor selain negara terhadap kejahatan penggunaan tentara anak dalam hukum humaniter internasional? Penelitian ini merupakan penelitian normatif, menggunakan pendekatan perundang-undangan, historis, dan konseptual. Hasil penelitian ini menyimpulkan: Pertama, praktik penggunaan tentara anak di lapangan oleh aktor selain negara dilakukan dengan merekrut tentara anaknya secara paksa dan sukarela, memerlakukan dengan sangat tidak manusiawi, serta menugasi berbagai macam pada tentara anak di pihak mereka berdasarkan usia dan jenis kelamin; Kedua, pertanggungjawaban yang diemban seseorang yang melakukan kejahatan penggunaan tentara anak dapat berupa tanggung jawab individu maupun tanggung jawab komando.

Kata-kata Kunci: Aktor selain negara; konflik bersenjata; tentara anak 


\section{Pendahuluan}

Praktik perekrutan anak menjadi kombatan masih banyak terjadi. Beberapa data menyatakan bahwa setidaknya terdapat 300.000 tentara anak yang terlibat dalam konflik bersenjata, ${ }^{1}$ meskipun sebenarnya yang terjadi bisa saja lebih dari jumlah itu. ${ }^{2}$ Hingga 2018, terdapat kurang lebih 14.000 anak yang berpartisipasi langsung dalam konflik bersenjata di Republik Afrika Tengah. ${ }^{3}$ Tercatat pula sebanyak 19.000 anak direkrut oleh kelompok bersenjata dan angkatan bersenjata di Sudan Selatan sejak 2014 hingga 2018. ${ }^{4}$ Bahkan sebanyak 203 anak dimanfaatkan sebagai media bom bunuh diri oleh Boko Haram di Nigeria dan Kamerun. ${ }^{5}$

Perekrutan tentara anak ini dapat menimbulkan penderitaan besar terhadap diri anak tersebut. Anak yang menjadi kombatan langsung dalam suatu konflik sering dipaksa melakukan sejumlah pengalaman mengerikan dalam hidupnya. ${ }^{6}$ Sebagian besar dari anak-anak tersebut dipaksa untuk melakukan kejahatankejahatan perang tanpa memiliki kemampuan untuk menolak perintah tersebut. ${ }^{7}$

Perekrutan tentara anak yang dilakukan oleh aktor selain negara sering tidak terkontrol. Berbeda dengan negara yang memiliki register dan mekanisme perekrutan angkatan bersenjata, aktor selain negara lebih sering melakukan perekrutan secara acak. Seperti yang terjadi di beberapa negara di Afrika, kelompok bersenjata aktor selain negara menculik anak-anak dari desa yang diserang dan kemudian menaikkan anak-anak ke truk-truk. ${ }^{8}$ Anak-anak ini kemudian dilatih singkat dan beberapa hari kemudian dipaksa maju ke garis depan pertempuran.

\footnotetext{
1 EU Guidelines on Children and Armed Conflict, 2008, terdapat dalam http://europa.eu/legislation_summaries/human_rights/human_rights_in_third_countries/r1013_en.htm diakses pada 25 Oktober 2018 Pukul 06:27.

2 Magne Frostad, "Child Soldiers: Recruitment, Use and Punishment", International Family Law, Policy and Practice, Vol. 1.1, Tromsø, 2013, hlm. 1.

3 Anonim, Child Soldiers International Annual Report 2017-18, Child Soldiers International, London, 2018, halaman 5.

${ }^{4}$ Ibid, lihat juga "Recruitment of Child Soldiers Still Rising in South Sudan", Aljazeera.com, 12 Februari 2018, diakses pada 24 Oktober 2018 Pukul 15:30 WIB.

${ }^{5}$ Ibid.

${ }^{6}$ Megan Nobert, "Children at War: The Criminal Responsibility of Child Soldiers", Jurnal Pace International Law Review Online Companion, Volume 3, Number 1, 2011, hlm. 3.

7 Pernyataan dari Peter, 12 tahun, seorang tentara anak di Sierra Leone ketika diwawancarai Amnesty International, ia menyatakan "When I was killing, I felt like it wasn't me doing these things. I had to because the rebels threatened to kill me", dalam Putusan The Special Court for Sierra Leone, Case No. SCSL-2003-08-PT, The Prosecutor v. Sam Hinga Norman, hlm. 4.

${ }^{8}$ Media Indonesia, Edisi Selasa 7 September 2010, Mereka Dipaksa Jadi Tentara, hlm. 28.
} 
Perekrutan tentara anak secara umum dilarang oleh hukum internasional. Namun selama ini, pengaturan-pengaturan pada instrumen hukum internasional di atas menekankan kewajiban pada subjek negara. Padahal penggunaan tentara anak oleh aktor selain negara lebih banyak terjadi. ${ }^{9}$ Hal ini mengakibatkan ketidakjelasan pengaturan hukum terhadap penggunaan tentara anak oleh aktor selain negara.

Hal tersebut terlihat pada diksi yang digunakan pada beberapa instrumen hukum humaniter internasional. Pada Protokol Pilihan Kedua dari Konvensi Hak Anak mengenai Keterlibatan Anak dalam Konflik Bersenjata misalnya, digunakan istilah Negara Peserta sebagai subyek yang diatur kewajibannya. Begitu juga dalam Konvensi Jenewa digunakan diksi the High Contracting Parties yang merupakan negara-negara peserta sebagai subyek pengemban kewajiban.

Oleh sebab itu, diperlukan riset khusus untuk menelaah bagaimana sebenarnya praktik penggunaan tentara anak. Penelitian ini penting guna mengetahui bagaimana sebenarnya hukum internasional mengatur sekaligus diterapkan untuk memberi pelindungan terhadap tentara anak yang direkrut dan digunakan oleh aktor selain negara. Penelitian ini tentu relevan dalam rangka memberi manfaat untuk kemajuan studi hukum humaniter di Indonesia ditengah masih minimnya penelitian mengenai permasalahan ini.

\section{Rumusan Masalah}

Berdasarkan latar belakang masalah di atas maka penulis merumuskan permasalahan sebagai berikut: pertama, bagaimana praktik penggunaan tentara anak oleh aktor selain negara? kedua, bagaimana konsep pertanggungjawaban aktor selain negara terhadap kejahatan penggunaan tentara anak dalam hukum humaniter internasional?

\section{Tujuan Penelitian}

Penelitian ini bertujuan: pertama, untuk menganalisa bentuk praktik penggunaan tentara anak oleh aktor selain negara; kedua, untuk menganalisabentuk konseppertanggungjawaban aktor selain negara terhadap kejahatan penggunaan tentara dalam hukum humaniter internasioanl.

\footnotetext{
${ }_{9}$ Child Soldiers World Index Reveals Shocking Scale of Child Recruitment Around the World, terdapat dalam https://www.child-soldiers.org/news/child-soldiers-world-index-reveals-shocking-scale-of-childrecruitment-around-the-world, diakses pada 8 Mei 2019 Pukul 08.26 WIB.
} 


\section{Metode Penelitian}

Penelitian ini merupakan jenis penelitian hukum normatif. Metode pendekatan yang digunakan adalah pendekatan perundang-undangan (treaty approach), historis, kasus, dan konseptual. Pendekatan perundang-undangan digunakan untuk meninjau aturan hukum apa saja yang digunakan dan mengatur tentang penggunaan tentara anak. Pendekatan historis dilakukan dalam rangka memahami filosofi dari aturan hukum dari waktu ke waktu serta memahami perubahan dan perkembangan filosofi yang mendasari aturan hukum tersebut. Pendekatan kasus digunakan untuk memahami peristiwa-peristiwa penggunaan tentara anak oleh aktor selain negara dalam konflik-konflik bersenjata yang terjadi di negara sampel. Pendekatan konseptual dilakukan untuk memahami prinsip-prinsip yang berlaku dalam hukum humaniter.

Sumber data yang digunakan dalam penelitian ini mengambil dari bahan hukum primer, bahan hukum sekunder, dan bahan hukum tersier. Bahan hukum primer yang digunakan merupakan pelbagai konvensi dan protokol hukum internasional. Penelitian ini mengambil sampel data dari sepuluh negara. Kesepuluh negara tersebut adalah: Sierra Leone, Liberia, Republik Demokratik Kongo, Republik Afrika Tengah, Republik Sudan Selatan, Kolombia, Myanmar, Syiria, Filipina, dan Indonesia. Kesepuluh negara ini dipilih sebagai sampel berdasarkan tingkat banyaknya kasus penggunaan tentara anak, tingginya intensitas konflik, serta mewakili dari benua atau regional yang ada di dunia.Data yang diperoleh kemudian diolah dengan metode deskriptif kualitatif.

\section{Hasil Penelitian dan Pembahasan}

\section{Penggunaan Tentara Anak oleh Aktor selain Negara}

Istilah tentara anak mulai muncul pada 1997 melalui Cape Town Principles, ${ }^{10}$ yang kemudian kembali dibahas oleh Paris Principles. ${ }^{11}$ Pada kedua ketentuan tersebut, digunakan batasan usia di bawah 18 tahun untuk mengkategorisasikan

10 Mark Drumbl, Children, Armed Violence and Transition: Challenges for International Law \& Policy, makalah disampaikan dalam Seminar Remarks: Children and International Criminal Justice, University of Georgia School of Law Conference on Children and International Criminal Justice, University of Georgia School of Law, 28 Oktober 2014, hlm. 623.

${ }^{11}$ Ibid. 
anak dan tentara anak. ${ }^{12}$ Jika melihat pada Cape Town Principles, definisi tentara anak dapat dipahami sebagai berikut:

Tentara anak adalah setiap orang di bawah umur 18 tahun yang merupakan bagian dari setiap bentuk, baik regular maupun irregular, pasukan bersenjata atau kelompok bersenjata didalamnya termasuk tetapi tidak terbatas pada tukang masak, porter, pengirim pesan, dan mereka yang menemani suatu kelompok bersenjata, selain murni sebagai anggota keluarga (dalam kelompok tersebut). ${ }^{13}$

Meski demikian, perkembangan terminologi tentara anak saat ini berkembang pesat hingga meliputi mata-mata, tukang masak, porter, budak seks, mitra suamiisteri paksa, hingga pejuang, baik bersenjata maupun tidak, ${ }^{14}$ bahkan batasan usia yang digunakan bervariasi hingga usia 15 tahun. ${ }^{15}$ Secara umum, Konvensi Jenewa menggunakan batasan 15 tahun untuk usia maksimal seorang anak. ${ }^{16}$

Mark Drumbl menyebutkan bahwa tidak ada tipikal murni tentara anak. ${ }^{17}$ Peristilahan tentara anak menurutnya adalah wujud dari sensasionalisme dan stereotip ketika membicarakan perekrutan anak guna kepentingan militer (childsoldering). ${ }^{18}$ Mereka adalah anak-anak yang terhubung dan terlibat dengan kelompok bersenjata. ${ }^{19}$ Sehingga menurutnya, tentara anak tidak melulu merujuk pada anak-anak yang menjadi kombatan seperti yang dimaksud Konvensi Jenewa, tetapi lebih kepada mereka yang terlibat dalam suasana militer kelompok bersenjata, baik pemerintah maupun pemberontak.

Berdasarkan hasil penelitian terhadap penggunaan tentara anak di sepuluh negara yang berbeda yang dilakukan penulis, ${ }^{20}$ terdapat fakta bahwa penggunaan tentara anak marak dilakukan oleh kelompok bersenjata bukan negara. Praktik penggunaan tentara anak ini dapat dipahamimelalui pola-pola pada praktik

${ }^{12}$ Ibid.

13Ziori Olga, Child Soldiers: Deprivation of Childhood a Critical Analysis of the International Humanitarian Law and International Human Rights Standards for the Protection of Children from Recruitment and Use in Armed Conflict,Desertasi, University of Bristol, Bristol, 2010,hlm. 11.

${ }^{14}$ Ibid.

15 Pasal 77 ayat (2) Protocol Additional to the Geneva Conventions of 12 August 1949, and Relating to the Protection of Victims of International Armed Conflicts (Protocol I), of 8 June 1977.

${ }^{16}$ Magne Frostad, loc.cit.

${ }^{17}$ Mark Drumbl, loc.cit.

${ }^{18}$ Ibid.

${ }^{19}$ Ibid.

${ }^{20}$ Penelitian ini dilakukan melalui studi literatur, dengan mengumpulkan pelbagai laporan, pemberitaan, dan kajian/penelitian terhadap kondisi konflik bersenjata yang terjadi di sepuluh negara yang dijadikan sampel oleh penulis. 
penggunaan tentara anak. Pola tersebut dapat dicermati pada kecenderungan aktor selain negara dalam memperlakukan tentara anaknya dalam hal perekrutan, perlakuan, dan penugasannya. ${ }^{21}$

\section{Pola Perekrutan Tentara Anak oleh Aktor Selain Negara}

Berdasarkan penelitian penulis, dapat diketahui bahwa aktor selain negara melakukan perekrutan dengan dua cara, yaitu secara paksa maupun membuka kesempatan anak-anak untuk mendaftar secara sukarela. Metode yang digunakan untuk mendukung perekrutan tentara anak oleh aktor selain negara adalah sebagai berikut:22

Tabel 1.

Pola Perekrutan Tentara Anak

\begin{tabular}{cc}
\hline Paksaan & Sukarela \\
\hline Penculikan & Propaganda \\
Ancaman & Informasi bias \\
& Persuasif/bujuk rayu \\
& Pola balas dendam \\
\hline
\end{tabular}

Secara paksa, kelompok bersenjata menggunakan metode penculikan dan/atau ancaman untuk merekrut tentara anak. Kelompok bersenjata biasanya melakukan penculikan dari desa-desa yang mereka jadikan sasaran. Pada konflik di Sudan Selatan, seorang anak bernama John diculik saat ketika hendak pergi ke ladang, ${ }^{23}$ dan kemudian dipaksa bergabung dan bertempur untuk South Sudan's National Liberation Movement. ${ }^{24}$ Selain di Sudan Selatan, anak-anak usia 16 dan 17 tahun di Aceh juga diancam akan dibunuh jika menolak bergabung ke dalam Gerakan Aceh Merdeka, ${ }^{25}$ dan akan dianggap sebagai mata-mata pemerintah. ${ }^{26}$

21 Pola ini dirumuskan untuk dapat mempermudah memahami penggunaan tentara anak oleh aktor selain negara. Pembagian pola ini didasarkan pada rezim pelindungan yang diberikan oleh hukum internasional yang meliputi pelarangan perekrutan, pelindungan hak-hak anak dalam konflik bersenjata, dan pelindungan anak ketika dalam medan tempur.

${ }^{22}$ Diolah dari pelbagai sumber.

${ }^{23}$ John saat itu berusia 15 tahun, terdapat dalam Hiba Morgan, Recruitment of child soldiers still rising in South Sudan", Al Jazeera, 12 Februari 2018, terdapat dalam https://www.aljazeera.com/news/2018/02/unicefroad-soldier-child-biggest-challenge-180212102306805.html, diakses pada 7 April 2019.

${ }^{24}$ Ibid.

25 Peristiwa ini terjadi pada kurun waktu berlakunya Daerah Operasi Militer di Provinsi Nangroe Aceh Darussalam

26 Anonim, Indonesia a Cycle of Violence for Aceh's Children, Amnesty International, 2000, hlm. 6. 
Untuk menarik minat anak-anak agar bergabung secara sukarela, kelompok bersenjata menggunakan beberapa cara atau metode. Pertama, adalah melalui propaganda. Kelompok bersenjata memanfaatkan penyebaran ide-ide tertentu, ${ }^{27}$ faham insurgensi, ${ }^{28}$ kisah-kisah pahlawan, ${ }^{29}$ sekolah atau institusi pendidikan, ${ }^{30}$ serta informasi tentang kondisi sosial yang butuh perlawanan, ${ }^{31}$ untuk mendapatkan atensi dan menyugesti anak-anak agar bergabung. Kedua, dengan menyebarkan informasi mengenai syarat dan teknis pekerjaan apabila bergabung menjadi tentara anak. Ketiga, dengan menggunakan bujuk rayu, seperti yang dilakukan oleh kelompok Islamic State (IS). ${ }^{32}$ Keempat, dengan memanfaatkan hasrat balas dendam anak-anak. Dengan didorong propaganda dan bujuk rayu yang telah dilakukan, kelompok bersenjata menjanjikan kesempatan kepada anak-anak untuk membalaskan dendam mereka kepada pasukan pemerintah.

Eric misalnya, mengaku bergabung dengan Liberians United for Reconciliation and Democracy (LURD) untuk membalas dendam pada tentara pemerintah. ${ }^{33}$ Beberapa alasan yang melatar belakangi anak-anak mendaftar secara sukarela antara lain: gaji atau penghasilan; semangat untuk melindungi keluarga, tanah dan tempat tinggal; semangat untuk menumbangkan pemerintah yang menindas; tuntutan berjihad; kehormatan untuk keluarga; balas dendam; serta keamanan dan keselamatan. ${ }^{34}$

Selain itu, terdapat juga dorongan dari masyarakat dan lingkungan agar anak-anak bergabung menjadi tentara anak. ${ }^{35}$ Terdapat beberapa alasan mengapa masyarakat melakukan hal tersebut, antara lain: untuk melindungi diri dari

27 Umum dilakukan hampir semua kelompok bersenjata di sepuluh negara yang dijadikan sampel penelitian.

${ }^{28}$ Dilakukan oleh semua kelompok bersenjata di sepuluh negara yang dijadikan sampel penelitian.

${ }^{29}$ Dilakukan oleh kelompok Islamic State (IS) di Syiria.

${ }^{30}$ Dilakukan oleh kelompok bersenjata di Kolombia, Myanmar, Filipina, dan Syiria.

${ }^{31}$ Umum dilakukan hampir semua kelompok bersenjata di sepuluh negara yang dijadikan sampel.

32 IS membelikan mainan, uang, dan gawai kepada anak-anak agar mau diajak ke markas persembunyian mereka, di sana anak-anak dicekoki dengan doktrin, propaganda, dan faham insurgensi.

33 Suatu hari, tujuh orang milisi pemerintah mendatangi rumah Eric. Mereka mengikat Eric dan memukulinya, memerkosa ibu dan dua saudara perempuannya secara bergilir, serta memaksa Eric untuk melihat semua itu. "So, I had to go and fight them to revenge my mother and sisters", terdapat dalam Human Right Watch, How to Fight, How to Kill Child Soldiers in Liberia, terdapat dalam ttps://www.hrw.org/report/2004/02/02/how-fighthow-kill/child-soldiers-liberia, diakses pada 27 Maret 2019.

${ }^{34}$ Diolah dari pelbagai sumber.

${ }^{35}$ Lihat http:/ / time.com/5290083/child-soldiers-central-african-republic/, diakses pada 29 Maret 2019. 
serangan kelompok lain; pandangan bahwa anak-anak sudah dewasa, atau; tuntutan berjihad. ${ }^{36}$

Selain masyarakat, orang tua juga mendorong anak-anaknya mendaftar pada kelompok bersenjata dengan alasan yang sama. Adakalanya orang tua menyuruh anaknya menjadi tentara anak dengan alasan materi. Kelompok bersenjata menjanjikan sejumlah uang pada keluarga yang bersedia menyerahkan anaknya.

Pihak yang menjadi perekrut tentara anak dipihak aktor selain negara berdasarkan penelitian ini dapat diklasifikasikan, antara lain: milisi/kombatan kelompok bersenjata; anggota kelompok bersenjata yang khusus sebagai perekrut; atau tentara anak lain. ${ }^{37}$

Milisi/kombatan kelompok bersenjata biasanya melakukan perekrutan tentara anak setelah menyerang desa-desa sipil. Pada 2003, LURD menyerang camp pengungsian di Montserrado, Liberia. Setelah penyerangan, penduduk sipil kemudian dipaksa mundur bersama LURD. Mereka menjadikan anak-anak sebagai target untuk dibawa serta, kemudian dilatih untuk bertempur. ${ }^{38}$ Johnny S., yang waktu itu berusia 17 tahun, mengaku telah dibawa oleh LURD setelah penyerangan di Montserrado. ${ }^{39}$ Ia dan anak-anak lain dibawa ke wilayah Bomi untuk dilatih.

Kelompok bersenjata juga memiliki anggota khusus untuk melakukan perekrutan tentara anak. Biasanya, para anggota khusus yang melakukan perekrutan menyebarkan propaganda atau cara-cara persuasif untuk menarik minat anak-anak. Selain propaganda, mereka juga menyampaikan informasi bias yang menjebak, ${ }^{40}$ agar anak-anak mau bergabung. ${ }^{41}$ Ada juga yang anggota khususnya secara aktif

\footnotetext{
${ }^{36}$ Diolah dari pelbagai sumber.

${ }^{37}$ Diolah dari pelbagai sumber.

38 Human Right Watch, How to Fight, How to Kill Child Soldiers in Liberia, terdapat dalam ttps://www.hrw.org/report/2004/02/02/how-fight-how-kill/child-soldiers-liberia, diakses pada 27 Maret 2019. ${ }^{39} \mathrm{Ibid}$

${ }^{40}$ Informasi bias yang dimaksud adalah kelompok bersenjata dengan sengaja memberikan informasi yang tidak jelas mengenai tugas dan rincian kerja yang harus dilakukan jika anak-anak bergabung dengan mereka, tidak atau memberi informasi yang salah mengenai kondisi medan pertempuran, dan/atau tidak menginformasikan bahwa terdapat batasan usia minimal untuk bergabung.

${ }^{41}$ Diolah dari pelbagai sumber.
} 
melakukan perekrutan dengan memisahkan anak-anak dari keluarga mereka, ${ }^{42}$ memberikan beberapa hadiah, dan kemudian merekrut mereka. ${ }^{43}$

Kelompok bersenjata juga menugaskan tentara anak mereka untuk melakukan perekrutan. Seperti yang terjadi pada Hassan, ${ }^{44}$ yang mengaku akan diberi beberapa hadiah jika berhasil merekrut tentara anak lain. ${ }^{45}$

Selain melalui perekrut, terdapat juga anak-anak yang secara aktif mendatangi kelompok bersenjata untuk menyatakan diri bergabung. Anak-anak bergabung dengan bermacam alasan. Beberapa alasan yang melatar belakangi anak-anak mendaftar secara sukarela antara lain:46 gaji atau penghasilan; semangat untuk melindungi keluarga, tanah dan tempat tinggal;semangat untuk menumbangkan pemerintah yang menindas; tuntutan berjihad; kehormatan untuk keluarga; balas dendam, serta; keamanan dan keselamatan.

\section{Pola Perlakuan terhadap Tentara Anak oleh Aktor Selain Negara}

Terdapat beberapa alasan mengapa kelompok bersenjata menggunakan tentara anak. Tentara anak dianggap murah, patuh, tidak mempertanyakan perintah, dan tidak membahayakan posisi politik komandan mereka. ${ }^{47}$ Namun, tetap saja anak-anak terkadang sulit untuk memahami perintah yang diberikan atau ketakutan di medan tempur. Guna mengatasinya, aktor selain negara akan melakukan cara apapun untuk menjadikan tentara anaknya efektif di medan

42 Teknik ini dilakukan oleh IS. Perekrut IS sengaja mengincar anak-anak dari latar belakang tertentu untuk direkrut. Anak-anak dari keluarga yang memiliki sedikit orang dewasa, keluarga yang bercerai, atau sering mendapat kekerasan dalam rumah menjadi prioritas operasi mereka.

43 IS melakukan perekrutan dengan cara tersebut. Jihadis IS melakukan serangkaian taktik untuk dapat merekrut tentara anak. Mereka memisahkan anak-anak dari orang tuanya dengan iming-iming yang menyenangkan anak. Ahmad, seorang anak berusia 13 tahun yang tinggal di Raqqa, suatu hari pulang dengan membawa telepon pintar baru. Pada hari yang lain ia pulang dengan membawa sejumlah uang. Baru beberapa lama kemudian, kakaknya menemukan sebuah foto Ahmad membawa senapan AK-47 bersama dengan jihadis IS di sekitarnya. Terdapat dalam Asaad Almohammad, "ISIS Child Soldiers in Syria: The Structural and Predatory Recruitment, Enlistment, Pre-Training Indoctrination, Training, and Deployment”, ICCT Research Paper, Volume 8 Number 4, the Hague, 2018, hlm. 7. Tengah.

44 Seorang tentara anak berusia 11 tahun yang tergabung dengan kelompok Séléka di Republik Afrika

${ }^{45}$ Jack Losh, "Child Soldiers in Central African Republic on the Rise", Pulitzer Center, terdapat dalam https://pulitzercenter.org/reporting/child-soldiers-central-african-republic-rise, diakses pada 29 Maret 2019.

46 Diolah dari pelbagai sumber

47 Shelly Whitman, et al, Child Soldiers: A Handbook for Security Sector Actors, The Roméo Dallaire Child Soldiers Initiative, Halifax, 2012, hlm. 37. 
pertempuran. Salah satunya mempersiapkan mental tentara anaknya, pihak aktor selain negara di sepuluh negara tersebut melakukan tindakan sebagai berikut:48

Tabel 2.

Pola perlakuan tentara anak yang paling dominan oleh aktor selain negara di sepuluh negara berbeda

\begin{tabular}{lll}
\hline \multicolumn{1}{c}{ Negara } & \multicolumn{1}{c}{ Metode Tindakan } & \multicolumn{1}{c}{ Sarana } \\
\hline Sierra Leone & Indoktrinasi dan cuci otak & Narkotika, ancaman \\
Liberia & Indoktrinasi dan cuci otak & Narkotika, ancaman \\
RDK & Indoktrinasi dan cuci otak & Narkotika, ancaman \\
Republik Afrika Tengah & Indoktrinasi dan cuci otak & Narkotika, ancaman \\
Sudan Selatan & Indoktrinasi & Masyarakat, mitos, agama \\
Kolombia & Indoktrinasi & Sekolah \\
Myanmar & Indoktrinasi & Sekolah, mitos \\
Syiria & Indoktrinasi dan cuci otak & Propaganda, \\
& & sekolah, narkotika \\
Filipina & Indoktrinasi & Propaganda, agama \\
Indonesia & Indoktrinasi & Ancaman, agama \\
\hline
\end{tabular}

Metode tindakan pada tabel di atas merujuk pada cara yang digunakan oleh kelompok bersenjata aktor selain negara di negara tertentu untuk menyiapkan mental atau psikis tentara anaknya. Upaya tersebut dilakukan untuk menumbuhkan kesetiaan dan disiplin militer pada tentara anak. Indoktrinasi adalah metode yang umum dilakukan dengan mengajarkan ideologi insurgensi pada tentara anak. Sedangkan metode cuci otak dilakukan secara ekstrem dengan menanamkan nilai insurgensi dalam alam bawah sadar tentara anak dengan menggunakan sarana tertentu. ${ }^{49}$

\section{Pola Penugasan terhadap Tentara Anak oleh Aktor Selain Negara}

Sedangkan berdasarkan pola penugasannya, tentara anak dipihak aktor selain negara biasanya ditugaskan di garis depan. Pihak aktor selain negaratidak bertindak selayaknya memperlakukan anak.

${ }^{48}$ Diolah dari pelbagai sumber.

${ }^{49}$ Umumnya menggunakan narkotika, obat-obatan, dan minuman keras, terdapat dalam Colleen Kirby, Colleen Kirby, Child Soldiers: An Innocence Lost, Tesis, Eastern Michigan University, Ypsilanti, Michigan, 2015, hlm. 9. 
Tentara anak digabungkan dengan anggota milisi dewasa, diberi minuman keras, narkotika, ${ }^{50}$ bahkan disuruh melakukan dan/atau menjadi obyek kekerasan seksual. Beberapa lagi dijadikan budak oleh para perwira dan komandannya untuk mengurusi kebutuhan dan pekerjaan rumah tanpa dibayar. Sedangkan tentara anak perempuan dieksploitasi dan dijadikan budak seks.

\section{Pertanggungjawaban Hukum Aktor Selain Negara terhadap Kejahatan Penggunaan Tentara Anak}

Setelah diketahui betapa mengerikannya perlakuan aktor selain negara terhadap tentara anaknya, muncul pertanyaan apakah pengaturan hukum humaniter internasional tentang penggunaan tentara anak dapat diterapkan pada aktor selain negara? Hal ini karena, pada mulanya, hukum internasional merupakan produk dari kesepakatan antar negara. ${ }^{51}$ Oleh sebab itu, hukum internasional lebih banyak mengatur negara, dan dinilai belum bisa diterapkan terahadap aktor selain negara.

Hukum humaniter internasional merupakan salah satu cabang tertua hukum internasional. Hukum humaniter, yang sebelumnya dikenal sebagai hukum perang, 52 telah ada sejak sejarah manusia dan perang itu sendiri pertama muncul. Hampir mustahil menemukan kapan hukum humaniter lahir. ${ }^{53}$ Meski cukup klasik, namun hukum humaniter terus mengalami perkembangan sejalan dengan peradaban manusia. Perkembangan itu berlangsung dalam rangka upaya-upaya untuk memanusiakan perang. ${ }^{54}$

Penggunaan tentara anak pada dasarnyatelah dilarang oleh hukum hak asasi manusia internasional, hukum humaniter internasional, hukum pidana

${ }^{50}$ Sherieef Karoma, seorang tentara anak dari RUF, mengaku diberi kokain setiap pagi, siang, dan malam. Pasukan RUF memberi narkotika padanya melalui suntikan atau bubuk yang diiriskan di lengan. Selain Karoma, Lynette, 16 tahun, mengaku diberi kokain yang disebut 'brown-brown' yang dicampurkan pada makanan. Berdasarkan penuturannya, RUF menggunakan narkotika sebagai alat pencuci otak. Lynette, seorang tentara anak perempuan, menggambarkan bahwa anak-anak yang diberi narkotika disuruh untuk berteriak "I want kill, I want kill', dan kemudian diberi kerosin (sejenis bensin) untuk membakar desa.

51 SefrianiHukum Internasional Suatu Pengantar, Rajawali Pers, Jakarta, 2016, hlm. 2, lihat juga Knut D. Asplund, et al, Hukum Hak Asasi Manusia, Pusat Studi Hak Asasi Manusia Universitas Islam Indonesia, Yogyakarta, 2015, hlm. 52.

52 Arlina Permanasari, et al, Pengantar Hukum Humaniter, International Committee of the Red Cross, Jakarta, 1999, hlm. 5.

${ }^{53} \mathrm{Ibid}$, hlm. 12.

${ }^{54}$ Ibid. 
internasional, dan hukum buruh internasional. ${ }^{55}$ Meski demikian, masih saja banyak anak-anak yang terlibat dalam konflik bersenjata. Padahal penggunaan tentara anak dapat dikategorikan sebagai suatu kejahatan perang. ${ }^{56}$ Hal ini sebagaimana disebutkan di dalam Statuta Pembentukan Mahkamah Pidana Internasional atau International Criminal Court (ICC), yang lebih dikenal dengan nama Statuta Roma.

Sebelum Statuta Roma diberlakukan, ${ }^{57}$ praktik penggunaan tentara anak telah menjadi momok di beberapa negara. Salah satunya dalam konflik di Sierra Leone. ${ }^{58}$ Pasca konflik di Sierra Leone, dibentuklah Special Court for Sierra Leone (SCSL) pada awal 2002 sebagai bentuk respon Persatuan Bangsa-Bangsa (PBB) kepada pemerintah Sierra Leone agar membentuk suatu peradilan khusus yang menangani kasus kejahatan serius terhadap penduduk sipil dan Pasukan Perdamaian PBB dalam konflik bersenjata antara 1991 sampai 2002.59 Statuta pendirian SCSL secara khusus menyebutkan yurisdiksi SCSL untuk mengadili kejahatan penggunaan tentara anak. ${ }^{60}$ Namun, berbeda dengan ICC, yurisdiksi SCSL sangat terbatas. SCSL hanya dapat mengadili kasus kejahatan perang yang masuk ke dalam yurisdiksinya yang terjadi di Sierra Leone pada kurun waktu 1991 sampai dengan 2002.

Statuta Roma melarang praktik perekrutan anak-anak sebagai angkatan bersenjata pada suatu konflik bersenjata, baik pada konflik bersenjata internasional ${ }^{61}$ maupun non internasional. ${ }^{62}$ Pada kedua rumusannya, digunakanlah batasan usia di bawah 15 tahun untuk mengategorisasikan anak. Statuta Roma melarang praktik wajib militer, perekrutan, atau melibatkan secara langsung seorang anak ke dalam konflik bersenjata. Pasal 8 ayat (2) huruf b nomor xxvi Statuta Roma melarang penggunaan anak di bawah usia 15 tahun ke dalam angkatan bersenjata nasional

\footnotetext{
55 Ziori Olga, Child Soldiers: Deprivation of Childhood a Critical Analysis of the International Humanitarian Law and International Human Rights Standards for the Protection of Children from Recruitment and Use in Armed Conflict,Desertasi, University of Bristol, Bristol, 2010, hlm. 16.

${ }^{56}$ Kejahatan perang menjadi salah satu yurisdiksi ICC yang diatur dalam Statuta Roma.

${ }^{57}$ Statuta Roma mulai berlaku pada 1 Juli 2002.

58 Sierra Leone adalah sebuah negara di Benua Afrika. Pada 1991, kelompok-kelompok pemberontak lokal menyerang Sierra Leone dari arah Liberia dan mengakibatkan konflik berkepanjangan.

59 The Special Court for Sierra Leone Its History and Jurisprudence, terdapat dalam http://www.rscsl.org/, diakses pada 13 Maret 2019.SCSL berdiri pada 6 Januari 2002 sebagai hasil perjanjian antara PBB dan pemerintah Sierra Leone melalui Resolusi Dewan Keamanan PBB (DK-PBB) Nomor 1315 Tahun 2000.

${ }^{60}$ Pasal 4 huruf c Statute of The Special Court for Sierra Leone.

${ }^{61}$ Pasal 8 ayat (2) huruf b nomor xxvi Rome Statute of the International Criminal Court, 1998.

62 Pasal 8 ayat (2) huruf e nomor vii Rome Statute of the International Criminal Court, 1998.
} 
(national armed force) pada suatu konflik bersenjata internasional. ${ }^{63}$ Pasal tersebut juga melarang pelibatan anak-anak dalam suatu konflik bersenjata. Sedangkan Pasal 8 ayat (2) huruf e nomor vii mengatur pelarangan perekrutan anak dalam angkatan bersenjata (armed force) maupun kelompok bersenjata (armed group) dalam suatu konflik bersenjata non internasional. ${ }^{64}$

Pada prinsipnya, hukum humaniter internasional dan hukum pidana internasional menerapkan pertanggungjawaban individu yang melepaskan perbuatan individu dengan tindakan negara. ${ }^{65}$ Hal tersebut sesuai dengan pendapat hakim Mahkamah Nuremberg yang menganggap negara sebagai entitas abstrak.66 Sehingga, demi mewujudkan keadilan, maka pertanggung jawaban atas kejahatan yang dilakukan harus dilekatkan pada perorangan yang melakukannya. ${ }^{67}$ Hubungan antara hukum humaniter dan hukum pidana internasional ini dikenal sebagai Aliran New York. 68

Pada hukum humaniter, pelarangan pelibatan tentara anak dalam konflik bersenjata diatur dalam ketentuan Portokol I ${ }^{69}$ dan Protokol II ${ }^{70}$ Konvensi Jenewa. Melalui pengaturan Protokol I dan Protokol II inilah dapat kita jabarkan bagaimana konsep hukum humaniter internasional mengatur pihak-pihak yang memiliki tanggung jawab untuk tidak melibatkan anak dalam kondisi konflik bersenjata. Pada rezim hukum humaniter internasional, Protokol I mengatur tentang berlakunya hukum humaniter dalam kondisi konflik bersenjata internasional, sedangkan Protokol II menhatur tentang kondisi konflik bersenjata non internasional.

Pengaturan pelarangan penggunaan tentara anak dalam Protokol I dapat ditemukan pada Pasal 77. Pasal 77 Protokol I menyebut "the Parties to the conflict"

\footnotetext{
${ }^{63}$ Element of Crimes Statuta Roma 1998 Pasal 8 ayat (2) huruf b nomor xxvi poin 1.

${ }^{64}$ Element of Crimes Statuta Roma 1998 Pasal 8 ayat (2) huruf e nomor vii poin 1.

65 William A. Schabas, "Punishment of Non-State Actors in Non-International Armed Conflict", Fordham International Law Journal, Volume 26 Issue 4, Fordham University, 2002, hlm. 907.

66 Philippe Kirsch, "Applying the Principles of Nuremberg in the ICC", makalah disampaikan dalam Seminar Conference "Judgment at Nuremberg" beld on the 60th Anniversary of the Nuremberg Judgment, Washington University, St. Louis, USA, 30 September 2006, hlm. 3.

${ }^{67}$ Ibid.

68 Yustina Trihoni Nalesti Dewi, Kejahatan Perang dalam Hukum Internasional dan Hukum Nasional, Rajawali Pers, Jakarta, 2013, hlm. 43.Menurut aliran ini, hukum pidana internasional menjadi dasar legitimasi bagi pembentukan pengadilan kejahatan perang, yang merupakan ranah hukum humaniter.

${ }^{69}$ Protocol Additional to the Geneva Conventions of 12 August 1949 and Relating to the Protection of Victims of International Armed Conflictsof 8 June 1977.

${ }^{70}$ Protocol Additional to the Geneva Conventions of 12 August 1949 and Relating to the Protection of Victims of Non-International Armed Conflicts of 8 June 1977.
} 
atau 'pihak yang bersengketa' sebagai penyandang kewajibannya. ${ }^{71}$ Meskipun merujuk pada entitas negara, ${ }^{72}$ namun penggunaan nama 'pihak yang bersengketa' ini tidak hanya membatasi tanggung jawab melindungi anak-anak hanya dibebankan pada negara saja. Sebab, Protokol I juga menggunakan istilah 'pihak yang bersengketa' untuk merujuk pada organisasi pertahanan sipil. ${ }^{73}$ Pasal 77 ayat (2) Protokol I secara tegas melarang 'pihak yang bersengketa' melibatkan anak berusia di bawah usia 15 tahun dalam permusuhan secara langsung. ${ }^{74}$ Sehingga, dapat dinilai bahwa pihak yang dilarang menggunakan tentara anak bukan hanya negara saja. Namun, seperti yang diuraikan sebelumnya, belum jelas siapa sajakah yang dimaksud sebagai 'pihak yang turut bersengketa' ini.

Protokol II melarang perekrutan dan partisipasi, baik langsung maupun tidak langsung, anak di bawah 15 tahun di dalam suatu permusuhan. ${ }^{75}$ Pada Pasal 4 ayat (3) huruf c, Protokol II melarang perekrutan anak di bawah usia 15 ke dalam angkatan bersenjata atau suatu kelompok. Bunyi dari ketentuan pasal tersebut adalah sebagai berikut:"Chidren who have not attained the age of fifteen years shall neither be recruited in the armed forces or groups nor allowed to take part in hostilities." 76

Jika pengaturan di atas disandingkan dengan praktik penggunaan tentara anak yang sudah dibahas sebelumnya, dapat diidentifikasikan perbedaan penggunaan peristilahan angkatan bersenjata dan kelompok bersenjata. Angkatan bersenjata, atau armed forces, biasanya merujuk pada kesatuan yang memiliki disipilin militer, contoh seperti angkatan bersenjata FARDC,77 Tatmadaw Kyi, ${ }^{78}$ atau TNI. ${ }^{79}$ Sedangkan istilah kelompok bersenjata lebih banyak merujuk pada militer yang terpisah dengan negara atau kelompok bersenjata aktor selain negara. Sehingga, dapat dipahami

71 Pasal 77 ayat (1) dan (2) Protocol Additional to the Geneva Conventions of 12 August 1949, and Relating to the Protection of Victims of International Armed Conflicts (Protocol I), of 8 June 1977.

72 Sebab Protokol I lebih banyak mengatur mengenai konflik bersenjata antar negara.

73 Pasal 64 Protocol Additional to the Geneva Conventions of 12 August 1949, and Relating to the Protection of Victims of International Armed Conflicts (Protocol I), of 8 June 1977.

74 Pasal 77 ayat (2) Protocol Additional to the Geneva Conventions of 12 August 1949, and Relating to the Protection of Victims of International Armed Conflicts (Protocol I), of 8 June 1977.

75 Mohd Akram, International Humanitarian Law, Hague and Geneva Convention on War Crimes, War Victims, and Prisoner of War, International Law Book Services, Kuala Lumpur, 2005, hlm. 70-71.

76 Pasal 4 ayat (3) huruf c Protocol Additional to the Geneva Conventions of 12 August 1949, and Relating to the Protection of Victims of Non-International Armed Conflicts (Protocol II), of 8 June 1977

${ }^{77}$ Forces Arme'es de la Re' publique Démocratique du Congo, angkatan bersenjata pemerintah Kongo.

78 Angkatan bersenjata pemerintah Myanmar.

${ }^{79}$ Tentara Nasional Indonesia, angkatan bersenjata Republik Indonesia. 
bahwa Protokol II memberi ruang pengaturan pelarangan penggunaan tentara anak kepada aktor selain negara, yaitu kelompok bersenjata.

Hukum humaniter internasional, khususnya melalui Protokol I dan Protokol II, menyebut aktor selain negara yang ikut menjadi 'pihak yang turut bersengketa' dalam wujud kelompok bersenjata. ${ }^{80}$ Namun, tidak ada penjelasan detail apakah kelompok bersenjata ini termasuk dalam bentuk insurgent atau belligerent. Bahkan, sampai sejauh ini tidak ditemukan pihak mana saja yang menjadi sosok atau perwakilan yang dapat bergerak atas nama kelompok bersejata ini selayaknya negara dalam hukum internasional. Sehingga, hukum humaniter tidak dapat menjawab permasalahan mengenai pihak yang akan bertanggung jawab apabila kelompok bersenjata melanggar dan melakukan praktik penggunaan tentara anak.

Penegakan hukum humaniter internasional, sesuai dengan Aliran New York, kemudian ditegakkan melalui hukum pidana internasional. Berdasarkan hasil penelitian yang dilakukan penulis, hanya ada dua mahkamah pidana internasional yang dapat mengadili kejahatan penggunaan tentara anak. ${ }^{81}$ Kedua mahkamah tersebut adalah SCSL dan ICC. Hal tersebut diperoleh setelah dilakukan analisis pada setiap statuta pendirian mahkamah internasional untuk mengadili kejahatan perang yang ada sejak pasca Perang Dunia Kedua.

Menurut Statuta SCSL, representasi dari kelompok bersenjata yang dapat dikenakan tanggung jawab atas tindakan penggunaan tentara anak mengarah pada komandan kelompok bersenjata, perwira, atau perekrut secara langsung. ${ }^{82}$ SCSL menganut prinsip pertanggung jawaban individu. Jika merujuk pada Pasal 6, yang dibebankan tanggung jawab pidana adalah seorang yang merencanakan, menghasut, memerintahkan, melakukan, atau yang membantu atau bersekongkol, dalam perencanaan, persiapan, atau pelaksanaan kejahatan. ${ }^{83}$ Termasuk jika orang yang didakwa adalah pejabat atau kepala negara, maka tidak akan menghapuskan tanggung jawab pidananya. ${ }^{84}$ Statuta Roma juga menerapkan pertanggungjawaban

${ }^{80}$ Menurut ICRC, yang dimaksud sebagai kelompok bersenjata adalah suatu organisasi yang terlibat dalam konflik namun tidak tunduk dan menjawab panggilan dari suatu negara, lihat pada Vincent Bernard, "Understanding Armed Groups and the Applicable Law", International Review of the Red Cross, Volume 93 Number 882, June, ICRC, 2011, hlm. 262

81 diolah dari pelbagai sumber.

82 Pasal 1 ayat (1) Statute of The Special Court for Sierra Leone, 2000.

83 Pasal 6 ayat (1) Statute of The Special Court for Sierra Leone, 2000.

84 Pasal 6 ayat (2) Statute of The Special Court for Sierra Leone, 2000. 
individu dalam yurisdiksi ICC. Statuta Roma menyebutkan bahwa subyek hukum yang menjadi yurisdiksi dari ICC adalah seorang individu natural person. ${ }^{85}$

Selain tanggung jawab individu berlaku juga tanggung jawab komando. Komandan atau perwira yang berwenang dianggap bertanggung jawab secara pidana untuk kejahatan perang yang dilakukan oleh bawahan mereka atau ketika gagal mencegah kejahatan tersebut. ${ }^{86}$ Sehingga, bukan hanya komandan saja yang memiliki tanggung jawab komando, 87 namun juga berlaku dalam hubungan subordinat. 88

Setelah ditinjau dari pelbagai instrumen hukum internasional, maka dapat disimpulkan bahwapihak yang dimaksud sebagai aktor selain negaramerujuk pada kelompok bersenjata yang dibebani tanggung jawab individu dan tanggung jawab komando. Dari hasil penelitian penulis, skema pertanggung jawaban pidana kejahatan penggunaan tentara anak dalam konflik bersenjata dapat digambarkan dalam bagan sebagai berikut:

\section{Bagan 1.}

Pihak-pihak aktor selain negara yang bertanggung jawab atas penggunaan tentara anak

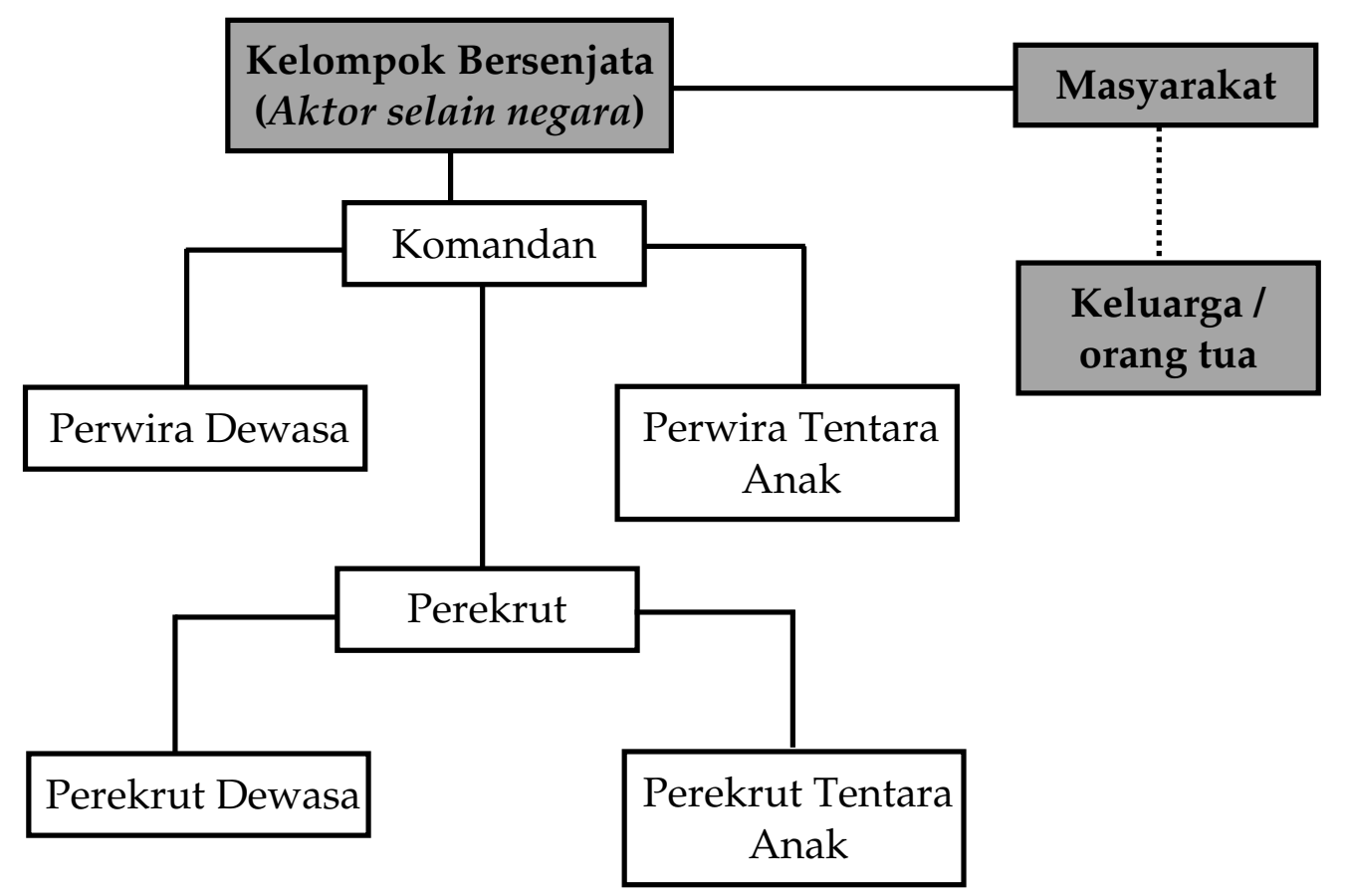

85 Pasal 25 ayat (1) Rome Statute of the International Criminal Court, 1998.

${ }^{86}$ Andrew Clapham, The Rights and Responsibilities of Armed Non-State Actors: The Legal Landscape \& Issues Surrounding Engagement, ADH Geneive, Geneva, 2010, hlm. 35.

${ }^{87}$ Pasal 28 huruf a Rome Statute of the International Criminal Court, 1998.

88 Pasal 28 huruf b Rome Statute of the International Criminal Court, 1998. 
Pihak selain negara yang bertanggung jawab atas adanya tentara anak terdiri dari kelompok bersenjata, masyarakat, dan keluarga/orang tua. Kelompok bersenjata menjadi aktor selain negara yang paling bertanggung jawab atas terjadinya perekrutan dan pelibatan tentara anak dalam konflik bersenjata. Hal ini sesuai dengan pengaturan Pasal 4 ayat (3) huruf c Protokol II. Fakta praktik di sepuluh negara sampel menunjukkan bahwa kelompok bersenjata secara aktif melakukan perekrutan tentara anak. ${ }^{89}$

Hal yang problematik adalah ternyata kelompok bersenjata turut menugaskan tentara anak mereka untuk aktif melakukan perekrutan. ${ }^{90}$ Selain itu, kelompok bersenjata juga memberikan jabatan perwira kepada anak-anak untuk memimpin satuan berisi anak-anak yang lain. ${ }^{91} \mathrm{Hal}$ ini mengakibatkan anak-anak ini secara skema turut memiliki pertanggungjawaban pidana kejahatan perang penggunaan tentara anak.

Statuta SCSL dan Statuta Roma ${ }^{92}$ mengatur ketentuan yang melarang mahkamah mengadili seorang tentara anak. Tetapi, secara khusus, Statuta SCSL memberikan mekanisme untuk mengadili seorang tentara anak yang berusia antara 15 sampai 18 ketika ia melakukan kejahatan tersebut. ${ }^{93}$ Sedangkan Statuta Roma tidak memungkinkan ICC untuk mengadili anak di bawah usia 18 tahun.

Pada praktik di beberapa negara, masyarakat dan orang tua turut mendorong anak-anak untuk bergabung dengan kelompok bersenjata. Terdapat beberapa alasan mengapa masyarakat dan orang tua mendorong anak-anak untuk bergabung dalam kelompok bersenjata. ${ }^{44}$ Namun, menurut mereka, tindakan itu merupakan 'pilihan terbaik' untuk anak. Padahal anak-anak akan mengalami pengalaman mengerikan setelah menjadi seorang tentara anak.

${ }^{89}$ diolah dari pelbagai sumber.

${ }^{90}$ diolah dari pelbagai sumber.

91 Tentara anak yang menjadi perwira dihadapkan pada kondisi serba salah. Pada satu sisi mereka merupakan perwira yang bertanggung jawab atas kejahatan perang penggunaan tentara anak, namun di sisi lain mereka juga tentara anak sebagai korban. Praktik penugasan seorang tentara anak sebagai perwira antara lain dilakukan oleh RUF dan Séléka.

92 Pasal 26 Rome Statute of the International Criminal Court, 1998, lihat juga Pasal 7 ayat (1) Statute of The Special Court for Sierra Leone, 2000.

${ }^{9}$ Pasal 7 ayat (1) Statute of The Special Court for Sierra Leone, 2000.

94 Hasil penelitian penulis menunjukkan bahwa alasan orang tua dan masyarakat mendorong anakanaknya agar bergabung menjadi tentara anak adalah: untuk melindungi diri dari serangan kelompok lain; pandangan bahwa anak-anak sudah dewasa, atau; tuntutan berjihad. 
Jika merujuk pada Statuta Roma, masyarakat dan orang tua bisa saja dipidanakan dan dituntut di hadapan ICC atas tindakan mereka mendorong anak bergabung dengan kelompok bersenjata. Hal ini sebagaimana disebutkan dalam Pasal 25 ayat (3) Statuta Roma yang menyebutkan bahwa setiap orang bersalah dan dapat dihukum di hadapan ICC apabila: melakukan kejahatan;95 memerintahkan, mengajak, atau memengaruhi melakukan tindakan kejahatan;96 dengan sengaja memfasilitasi, membantu, bersekongkol, atau mendukung tindakan kejahatan, dan/atau; ${ }^{97}$ dengan cara lain berkontribusi pada tindakan kejahatan oleh sekelompok orang yang bertindak dengan tujuan yang sama. ${ }^{98}$

\section{Penutup}

Berdasarkan rumusan masalah penelitian ini, dapat diambil kesimpulan sebagai berikut: pertama, praktik penggunaan tentara anak di lapangan oleh aktor selain negara dapat dipahami dari pola perekrutannya yang melalui mekanisme sukarela dan paksaan. Anak-anak direkrut oleh perekrut dewasa maupun oleh tentara anak lain. Masyarakat dan keluarga turut mendorong anak-anak bergabung ke dalam kelompok bersenjata. Kelompok bersenjata menyebarkan ideologi insurgensi untuk menarik simpati masyarakat dan menujukan pembenaran atas tindakan yang dilakukan, sehingga turut menjadi katalis bagi praktik perekrutan tentara anak. Tentara anak juga diperlakukan oleh kelompok bersenjata aktor selain negaraberaneka cara untuk membuat tentara anak efektif di medan pertempuran, seperti memberikan indoktrinasi dan cuci otak. Selain itu, anak-anak diberi tugas yang cukup bervariatif, berdasarkan pada usia dan jenis kelamin mereka. Anak-anak yang masih terlalu kecil biasanya tidak ditempatkan di garis depan. Mereka yang sudah dianggap 'cukup dewasa' diberi pelatihan militer dan ditugaskan mengangkat senjata di garis depan. Sedangkan anak-anak perempuan, secara khusus, biasanya ditugaskan sebagai budak seks atau mengurus kebutuhan sehari-hari.

Kedua, bahwa hukum humaniter internasional dapat diterapkan pada aktor selain negara. Penegakan hukum humaniter internasional ini dilakukan melalui

\footnotetext{
${ }_{95}$ Pasal 25 ayat (3) huruf a Rome Statute of the International Criminal Court, 1998

${ }^{96}$ Pasal 25 ayat (3) huruf b Rome Statute of the International Criminal Court, 1998

${ }^{97}$ Pasal 25 ayat (3) huruf c Rome Statute of the International Criminal Court, 1998

98 Pasal 25 ayat (3) huruf d Rome Statute of the International Criminal Court, 1998
} 
penerapan hukum pidana internasional tentang kejahatan perang. Melalui hukum pidana internasional, individu ditempatkan sebagai subyek hukum yang bertanggung jawab atas kejahatan perang yang dilakukan. Pertanggungjawaban yang diemban seseorang yang melakukan kejahatan penggunaan tentara anak dapat berupa tanggung jawab individu dan juga tanggung jawab komando. Aktor selain negara yang bertanggung jawab atas penggunaan tentara anak dalam konflik bersenjata adalah: kelompok bersenjata, masyarakat, dan keluarga/orang tua. Pada kelompok bersenjata ini berlaku juga tanggung jawab komando. Terdapat problematik ketika pucuk komando dan perekrut adalah juga seorang tentara anak. Pada kasus seperti ini, hanya SCSL yang dapat mengadili kejahatan perang yang dilakukan oleh seorang tantara anak, dengan syarat harus berusia antara 15 sampai 18 tahun ketika melakukan kejahatan tersebut.

\section{Daftar Pustaka}

\section{Buku}

Akram, Mohd, International Humanitarian Law, Hague and Geneva Convention on War Crimes, War Victims, and Prisoner of War, International Law Book Services, Kuala Lumpur, 2005.

Anonim, Child Soldiers International Annual Report 2017-18, Child Soldiers International, London, 2018.

Anonim, Indonesia a Cycle of Violence for Aceh's Children, Amnesty International, 2000.

Asplund, Knut D. et al, Hukum Hak Asasi Manusia, Pusat Studi Hak Asasi Manusia Universitas Islam Indonesia, Yogyakarta, 2015.

Clapham, Andrew, The Rights and Responsibilities of Armed Non-State Actors: The Legal Landscape \& Issues Surrounding Engagement, ADH Geneive, Geneva, 2010.

Permanasari, Arlina, et al, Pengantar Hukum Humaniter, International Committee of the Red Cross, Jakarta, 1999.

Sefriani, et al, Konteks dan Perspektif Politik terkait Hukum Humaniter Internasional Kontemporer, Rajawali Pers, Jakarta, 2015.

Sefriani, Hukum Internasional Suatu Pengantar, Rajawali Pers, Jakarta, 2016.

Verri, Pietro, Dictionary of the International Law of Armed Conflict, International Committee of the Red Cross, Jenewa, 1992.

\section{Jurnal}

Almohammad, Asaad, "ISIS Child Soldiers in Syria: The Structural and Predatory Recruitment, Enlistment, Pre-Training Indoctrination, Training, and Deployment", ICCT Research Paper, Volume 8 Number 4, the Hague, 2018. 
Frostad, Magne, "Child Soldiers: Recruitment, Use and Punishment", International Family Law, Policy and Practice, Vol. 1.1, Tromsø, 2013.

Nobert, Megan "Children at War: The Criminal Responsibility of Child Soldiers", Jurnal Pace International Law Review Online Companion, Volume 3, Number $1,2011$.

Schabas, William A. "Punishment of Non-State Actors in Non-International Armed Conflict", Fordham International Law Journal, Volume 26 Issue 4, Fordham University, 2002.

Schmitt, Michael N. , Wolf Heintschel von Heinneg, The Development and Principles of International Humanitarian Law, Routledge, New York, 2016.

\section{Hasil Penelitian/Tugas Akhir}

Kirby, Colleen, Child Soldiers: An Innocence Lost, Tesis, Eastern Michigan University, Ypsilanti, Michigan, 2015.

\section{Makalah}

Drumbl, Mark, Children, Armed Violence and Transition: Challenges for International Law $\mathcal{E}$ Policy, makalah disampaikan dalam Seminar Remarks: Children and International Criminal Justice, University of Georgia School of Law Conference on Children and International Criminal Justice, University of Georgia School of Law, 28 Oktober 2014.

Kirsch, Philippe, "Applying the Principles of Nuremberg in the ICC", makalah disampaikan dalam Seminar Conference "Judgment at Nuremberg" held on the 60th Anniversary of the Nuremberg Judgment, Washington University, St. Louis, USA, 30 September 2006.

Olga, Ziori, Child Soldiers: Deprivation of Childhood a Critical Analysis of the International Humanitarian Law and International Human Rights Standards for the Protection of Children from Recruitment and Use in Armed Conflict,Desertasi, University of Bristol, Bristol, 2010.

\section{Internet}

Child Soldiers Global Report 2008: Congo, Democratic Republic of the, terdapat dalam https://www.refworld.org/docid/486cb0f5c.html, diakses pada 31 Maret 2019.

Human Right Watch, How to Fight, How to Kill Child Soldiers in Liberia, terdapat dalam ttps://www.hrw.org/report/2004/02/02/how-fight-howkill/child-soldiers-liberia.

Permanasari, Arlina, Asas-asas Hukum Humaniter Internasional, terdapat dalam https: / /arlina100.wordpress.com/2008/11/15/asas-asas-hukumhumaniter/.

The Special Court for Sierra Leone Its History and Jurisprudence, terdapat dalam http:/ /www.rscsl.org/. 


\section{Peraturan Perundang-Undangan}

Protocol Additional to the Geneva Conventions of 12 August 1949, and Relating to the Protection of Victims of International Armed Conflicts (Protocol I), of 8 June 1977.

Protocol Additional to the Geneva Conventions of 12 August 1949, and Relating to the Protection of Victims of Non-International Armed Conflicts (Protocol II), of 8 June 1977

Rome Statute of the International Criminal Court, 1998.

Statute of The Special Court for Sierra Leone, 2000. 